\title{
Extremistas, enemigos, antipatriotas e indeseables: la legitimidad del golpe de Estado de 1973 en la prensa escrita de Concepción
}

\author{
Danny Monsálvez Araneda ${ }^{1}$ \\ Recibido: 18 de noviembre de 2013 Aceptado: 15 de enero de 2014
}

\begin{abstract}
Resumen
El presente artículo aborda el discurso de la prensa escrita en Concepción a propósito del golpe de Estado de 1973. Para aquello hemos revisado y analizado las editoriales y columnas de opinión de los principales periódicos de la ciudad, Diario El Sur, Crónica y El Diario Color. El resultado de aquello fue identificar qué circulaba pública y masivamente sobre el tema de la intervención militar del 11 de septiembre, así como dar cuenta del uso de un determinado lenguaje y conceptos que utilizaron aquellos periódicos para legitimar la intervención militar y las acciones de las Fuerzas Armadas en Concepción.
\end{abstract}

Palabras clave: Golpe de Estado 1973, Concepción, Prensa escrita, Legitimidad.

Extremists, Enemies, Anti-Patriots and Undesirables: The Legitimacy of the 1973 Coup d'état by Concepción's Newspapers

\begin{abstract}
This article discusses the writing-style of written press in Concepción on the subject of 1973 coup. With this goal, we have reviewed and analyzed the editorials and opinion columns from leading newspapers of the city, El Sur, Crónica and El Diario Color newspapers. The result was to identify what was widely published pon the subject of military intervention of 11 September, as well as to report the use of a particular language and concepts used by those newspapers to legitimize military intervention and the actions of the Armed forces in Concepción.
\end{abstract}

Keywords: Coup 1973, Concepción, Newspapers, Legitimacy.

1 Chileno, Doctor en Historia. Académico de Historia Política de Chile Contemporáneo, Departamento de Ciencias Históricas y Sociales, Universidad de Concepción. E-mail: monsalvez@ gmail.com. 


\section{Extremistas, inimigos, antipatriotas e indesejáveis: A legitimidade do golpe de Estado de 1973 na imprensa escrita de Concepção}

\section{Resumem}

0 presente artigo aborda o discurso da imprensa escrita em Concepção a propósito do golpe de Estado de 1973. Para aquilo temos revistado e analisado as editoriais e colunas de opinião dos principais periódicos da cidade, Jornal O Sul, Crônica e O Jornal Color. 0 resultado de aquilo foi identificar o que circulava pública e massivamente sobe o tema da intervenção militar do dia 11 de setembro, assim como dar conta do uso de uma determinada linguajem e conceitos que utilizaram aqueles jornais para legitimar a intervenção militar e as ações das Forcas Armadas em Concepção.

Palavras chave: Golpe de Estado 1973, Concepção, Imprensa escrita, Legitimidade.

Conocido es el papel que desempeñó la prensa escrita nacional durante el gobierno de la Unidad Popular. Como señala -entre otros- Ángel Soto Gamboa, "Tras el triunfo de Salvador Allende (1970), los medios de comunicación, escritos, radiales y televisivos jugaron un papel primordial en la agitación de las pasiones políticas que por entonces exacerbaban los ánimos de Chile"; en ese contexto situamos la prensa de izquierda, es el caso de El Clarín, El Siglo, Punto Final, La Nación y Última Hora. Mientras que la derecha hizo frente con las revistas PEC, SEPA, Qué Pasa y los diarios Tribuna, El Mercurio y La Segunda" (Soto, 2003: 98). Es decir, la prensa y los respectivos medios de comunicación fueron parte significativa del proceso de polarización ideológica que se desencadenó a nivel nacional, no desde la llegada de la izquierda al gobierno el año 1970, sino que desde los años sesenta en adelante. ${ }^{2}$

Después del golpe de Estado de 1973, la prensa siguió cumpliendo un papel fundamental, esta vez transmitiendo (reproduciendo) las informaciones que en gran parte emanaban desde las esferas del poder militar. "Para controlar la información accesible a la mayoría de los chilenos y restringir el conocimiento de los asuntos que debían formar parte de la opinión pública, el régimen militar invocó la defensa de la seguridad del Estado y las prevenciones para resguardar el orden público o los imperativos del receso político; montó un dispositivo jurídico, afinado con los años, que legalizó la censura y sanciones contra quienes vulneraran sus severas restricciones, reservándose

2 Un interesante trabajo que muestra el desarrollo de la prensa durante el gobierno de la Unidad Popular, en Arturo Fontaine y Miguel González. Los mil días de Allende. Tomo I y II. Santiago, Centro de Estudios Públicos, 1997. 
para sí la competencia para determinar en forma unilateral cuándo y cómo se atentaba contra aquello" (Informe Comisión Nacional Sobre Prisión Política y Tortura, 2004: 205).

Tras el golpe de Estado, la idea fue legitimar comunicacionalmente las acciones llevadas adelante por las Fuerzas Armadas y aquellos sectores civiles que las respaldaban. En ese contexto, conocido es el caso del diario El Mercurio, crítico y opositor al gobierno de Salvador Allende, el cual post 11 de septiembre de 1973 desempeñó un papel político, ideológico y comunicacional importante durante los diecisiete años de dictadura.

Como apunta María Olivia Monckeberg, "La formación de Agustín Edwards Eastman, sus convicciones económicas y políticas, y el rol que jugó para la generación del golpe, son elementos suficientes para explicar por qué, después de septiembre de 1973, el diario El Mercurio y toda su cadena cerró filas con la junta de gobierno". En ese sentido, "La dictadura encabezada por Augusto Pinochet era su propio gobierno al que había contribuido a promover para que pusiera orden en el país tras los turbulentos, y para él amenazantes, mil días de la Unidad Popular", de ahí que, "A tono con esos tiempos, El Mercurio acentuó su carácter conservador y cerró los ojos durante largos años a todo lo que significaba violaciones a los derechos humanos. Los desaparecidos eran "supuestos"; los asesinados por la espalda, "muertos en enfrentamientos; y las torturas no existían o, a lo más, eran "excesos" (Monckeberg, 2009: 102-104). Lo anterior quedó explicitado en el documental El Diario de Agustín, trabajo que da cuenta del papel que desempeñó el diario El Mercurio en materia de derechos humanos durante el régimen de Pinochet (Lagos, 2009).

A estas alturas es conocido el rol que desempeñó la prensa crítica con el gobierno de Salvador Allende, por lo tanto, partidarias del golpe de Estado y próxima a la dictadura cívico-militar, no obstante aquello, y como una forma de ampliar aquella perspectiva de análisis, situamos como problema de estudio en el presente artículo, analizar la prensa escrita, a propósito del golpe de Estado de 1973, pero en un espacio local; de ahí entonces que nos preguntemos ¿cuál fue el papel que desempeñaron los medios escritos fuera de Santiago?; es decir, en provincias y ciudades, particularmente en aquellas zonas donde la lucha política e ideológica se vivió con mayor intensidad, como es el caso de la ciudad de Concepción y sus alrededores, que hacia el 11 de septiembre de 1973, figuraba ante el mundo político y social como una "zona roja".

En vista de lo anterior, este artículo se plantea las siguientes interrogantes: ¿cuál fue el papel de la prensa en Concepción al momento del golpe de Estado?; ¿fue una mera reproducción de lo ocurrido en Santiago, de lo que procedía desde las esferas del mundo castrense, o tuvo sus propias expresiones 
y representaciones locales?; ¿ de qué forma la prensa en Concepción colaboró en la transmisión de ciertas imágenes y representaciones del momento, por ejemplo aquella del enemigo interno, los antipatriotas o extremistas? Para responder aquellas interrogantes, nos hicimos cargo de la prospección de la prensa escrita en Concepción al momento del golpe militar, nos estamos refiriendo a los diarios El Sur, Crónica y El Diario Color.

La metodología a utilizar consistió en analizar los editoriales y columnas de opinión. El objetivo de esta revisión fue entregar algunas claves para evaluar la circulación de ciertas ideas, opiniones y comentarios (proclives a la intervención militar), que constituyeron la lectura dominante en el espacio público, y así dar cuenta del uso de un determinado lenguaje y aparato conceptual que utilizaron dichos medios para comunicar o representar lo que estaba ocurriendo en la zona de Concepción.

Por lo tanto, estos periódicos deben ser analizados y entendidos como actores políticos del período. De ahí que, a nuestro parecer y como hipótesis señalemos que el papel de la prensa en la ciudad de Concepción en la coyuntura 1973, no fue solo convertirse en mero emisor de las informaciones oficiales; su objetivo fue mayor: por una parte, dar legitimidad ${ }^{3}$ a las acciones llevadas adelante por los militares, civiles y aparatos represivos del régimen, y, por otra, contribuir en la persuasión, crear cohesión, consenso en la población para que ésta aceptara (voluntariamente) todas las acciones que se estaban Ilevando adelante, ya que éstas tenían un objetivo superior, salvar a Chile, a la Patria de la amenaza marxista.

\section{La prensa de Concepción al momento del golpe de Estado de 1973}

Al momento del golpe de Estado, tres eran los diarios que circulaban en la ciudad de Concepción, el más antiguo era diario El Sur (1882), luego estaba diario Crónica (1949, perteneciente a la misma empresa) y, por último, El Diario Color (1971) vinculado a los partidos Comunista y Socialista.

En el caso del primero, se trata de un periódico de vasta trayectoria en la zona. Fundado el 15 de noviembre de 1882 por prominentes hombres de la ciudad (Casanueva, 2002: 254). ${ }^{4}$ En sus orígenes el diario estuvo fuertemente

3 De acuerdo a Norbert Lechner, "Por legitimidad entendemos el reconocimiento de un orden político. El reconocimiento se refiere al empleo del poder estatal para asegurar la integración social. Se basa en motivaciones y valores que permiten justificar el orden como bueno", en: Lechner, Norbert, Obras escogidas. Santiago, LOM Ediciones, 2006, p. 184.

4 Entre ellos Ignacio Ibieta Rioseco, Víctor Lamas Miranda, Agustín Vargas Novoa, Gregorio Burgos Figueroa, Lisandro Martínez Rioseco, Carlos Castellón Larenas, Beltrán Mathieu 
ligado al radicalismo, específicamente por la fuerza electoral que el partido tenía en la ciudad y el vínculo que existió con sus fundadores y propietarios. Al respecto, Fernando Casanova señala que "Los radicales de Concepción necesitaban un periódico. Una voz impresa y multiplicada. Así lo entendió el líder don Juan Castellón Larenas, que propició una erogación partidista para reunir el capital necesario" (Casanueva, 2002: 255). De ahí en adelante, el diario cumplió un papel importante, como expresión escrita para hacer presente las inquietudes políticas y económicas de la elite penquista y servir los intereses de la región a nivel nacional.

Será la misma empresa Diario El Sur, la que el 8 de febrero de 1949 decida lanzar un nuevo diario, pero dirigido a un público distinto al que leía $E /$ Sur. Se trataba del vespertino Crónica, el cual "logró llegar a un sector de la población que se interesó en el periódico que le entregaba noticias "frescas" después del mediodía" (Casanueva, 2002: 322).

Si diario El Sur, llegaba a los sectores de la elite penquista, Crónica, con un lenguaje distinto y algo coloquial lo hará hacia el mundo popular. Durante el gobierno de la Unidad Popular, el vespertino tuvo una posición muy crítica y de denuncia contra la administración socialista. Sus noticias, reportajes y titulares se enmarcaron en un sensacionalismo que buscó impactar fuertemente en la opinión pública local.

En ese sentido, mientras diario El Sur, tuvo un discurso crítico con la Unidad Popular, pero cuidando las formas, Crónica se transformó en el periódico de trinchera y batalla diaria contra el gobierno de Allende. Por eso, una vez producido el golpe de Estado, en sus páginas se leerá una abierta postura de apoyo a las nuevas autoridades y de diatriba contra el extinto gobierno de Salvador Allende. ${ }^{5}$

El 12 de marzo de 1971, salió a la luz pública El Diario Color. En un formato similar al de diario El Sur, pasó rápidamente a convertirse en un importante medio de lectura para un significativo sector de los habitantes del Gran Concepción, especialmente de aquellos que simpatizaban con el gobierno de la Unidad Popular.

Andrews, Luis Urrutia Rozas, Rafael de la Sotta Benavente, Mariano Palacios Daroch, y Víctor Manuel Rioseco Cruzat. Véase: Casanueva Herrera, Fernando, Prensa y periodismo en Concepción 1833-2000, Concepción, Escuela de Periodismo Universidad Católica de la Santísima Concepción, julio 2002, p. 254.

5 Varios fueron los directores que tuvo el vespertino durante su existencia (hasta enero del año 1984). Para el caso de nuestro estudio, el diario tuvo como directores a Iván Cienfuegos Uribe, Mario González Rosas y Luis Aravena Assensy. 
El Diario Color "fue en esos años un extraordinario y moderno medio de comunicación capaz de vehicular de manera periodística, especialmente los mensajes de gobierno y las ideas-acción de éste" (Casanueva, 2002: 339-340). En otras palabras, el diario tuvo una sensibilidad política próxima al gobierno de Salvador Allende, sin embargo, y a diferencia de otros periódicos de izquierda, no cayó en la condescendencia o incondicionalidad con el gobierno, más bien buscó, sin desconocer su inclinación, tener una mirada leal y sincera.

Al momento del golpe de Estado, su director era el periodista y abogado Bernardo Pelén Pucheu, el cual permanece en el cargo hasta octubre de 1973, luego es reemplazado por el designado Víctor Solar Manzano.

¿Quién fue el dueño o propietario de El Diario Color? En sus orígenes el diario fue de propiedad de Nuncio Ready Zablah y algunos integrantes de su familia, los cuales dan vida a la Sociedad Periodística Chile Limitada; sin embargo, los problemas económicos para sostener la edición del diario, llevaron a que en octubre de 1972, "los socios de Nuncio Ready deciden disolver la agrupación. Ante esto, venden su parte de las acciones a Jorge Peña (médico) e Iván Quintana (abogado), quienes eran miembros del partido Socialista y Comunista, respectivamente" (Caballero, 1997: 22-23).

Producido el golpe de Estado, desaparecen los bienes de propiedad de Peña y Quintana, es decir, el nuevo gobierno pasa a controlar aquella parte. A esto se sumó que en marzo de 1974, el Fisco junto a la Sociedad Periodística del Sur (SOPESUR), toman el control absoluto del medio; por lo tanto, el diario no sólo cambia de propietarios, también de línea editorial. De acuerdo a las versiones de quienes trabajaron en el periódico, su propietario vendió la totalidad de sus acciones a dicha agrupación. No obstante, Nuncio Ready niega tal transacción, señalando que el gobierno se apropió de su parte y se la cedió a ésta (Caballero, 1997: 32).

Lo cierto es que, tras el 11 de septiembre de 1973, El Diario Color pasó de ser un periódico próximo a la Unidad Popular, a tener una línea de apoyo irrestricto con la dictadura. Al igual que Crónica, no escatimó esfuerzos en denostar al gobierno de la Unidad Popular, sus partidarios y simpatizantes, así como a aquellos que tuvieron una posición crítica con la Junta Militar.

Para el caso de nuestro estudio, durante el período de la Unidad Popular, diario El Sur tuvo una voz crítica con el gobierno de Salvador Allende, especialmente en los aspectos políticos y económicos de la gestión socialista. Lo anterior generó más de algún problema y momento complejo para la familia Lamas Benavente, dueña del diario en esa época (Casanueva, 2002: 257)

Al respecto y con motivo del centenario del diario (1982), éste publicó una edición especial, la cual realizó un recorrido histórico por los principales 
hitos que habían marcado la historia del medio en estos cien años de vida "independiente y regionalista". En uno de aquellos suplementos se daba cuenta de los complejos y duros momentos que le correspondió vivir durante el gobierno de la Unidad Popular. Al respecto señaló: "Los días más cruciales se vivieron entre octubre y noviembre de 1972, cuando se declaró una huelga que, según sus impulsores, agrupados en el Frente Revolucionario de Trabajadores, FTR, que controlaba el sindicato, era la acción definitiva para traspasar el diario al poder de los trabajadores. Esto equivalía a decir que el Gobierno de entonces, presidido por Salvador Allende y apoyado por una coalición mayoritaria de partidos marxistas, tomaría el control de la publicación, ya que ese régimen se declaraba como "de los trabajadores" en la propaganda oficial" (Diario El Sur, 15-XI-1982: 66).

Se produjo una pugna por la ocupación y control de las instalaciones del diario, por una parte el sindicato de trabajadores, con el respaldo del gobierno de la Unidad Popular, y por otra, el Frente Unido de Trabajadores del diario, encabezados entre otros por Hernán Álvez, con el apoyo de sectores políticos, sociales y gremiales opositores al gobierno de Allende. Finalmente y después de dos meses de controversias, los empresarios, directivos y trabajadores lograron retener el diario y ponerlo en marcha.

Para quienes dirigían el diario, el gobierno de Allende buscó la estatización del periódico, de ahí, la acción del sindicato de tomarse el edificio y pasar a controlarlo. Sin embargo, "la gran mayoría ciudadana prestó su apoyo incondicional y sostenido a la lucha de EL SUR. Diez meses más tarde, las Fuerzas Armadas y de Orden respondían al llamado abrumador de los hombres y mujeres de Chile que, ante la imposibilidad de enmendar el rumbo del Gobierno por la vías legales, demandaban la toma del poder por la fuerza" (Diario El Sur, 15-XI-1982: 66).

Este hecho no fue menor, en medio del conflicto político e ideológico que se vivía, los medios nacionales y locales fueron tomando posición respecto al apoyo o rechazo al gobierno de Salvador Allende; en ese cuadro, El Sur se ubicó entre aquellos medios opositores al gobierno socialista; esto fue posible de apreciar en las informaciones que se entregaban, sus editoriales y respectivas columnas de opinión, dando tribuna a personajes y personeros que guardaban fila en la oposición.

\section{Editorializando (legitimando) el "pronunciamiento militar"}

Los editoriales pasaron a constituirse en un elemento central a la hora de comentar o expresar el punto de vista del diario o quienes eran sus dueños. De los tres medios a los cuales nos estamos refiriendo, dos de ellos, Crónica 
y El Diario Color, utilizaron sus editoriales para realizar comentarios y análisis políticos de la situación que atravesaba el país. Con un claro lenguaje partidario, no escondieron su simpatía con la Junta Militar, así como su crítica a todo aquello que tuvo relación con la Unidad Popular, la izquierda o el marxismo.

Al respecto, ¿cuáles fueron los temas o ideas-fuerza que circularon en los tres diarios penquistas? Estos giraron en torno a tres ejes, el primero de ellos fue la legitimación de la intervención militar, destacando y defendiendo las medidas que llevó adelante la Junta de Gobierno; el segundo, y relacionado con el anterior, la crítica (por momentos virulenta y despectiva) contra los opositores al régimen y contra aquellos que pertenecieron o tuvieron algún vínculo con el gobierno de la Unidad Popular; y el tercero, las alusiones y referencias a la figura de Diego Portales, los valores que el personaje representaba y encarnaba, particularmente para el momento que estaba viviendo el país.

A medida que se aproximaba el 11 de septiembre de 1973, diario El Sur hizo presente con mayor fuerza y preocupación la situación que se vivía en el país, por lo tanto, acrecentó su crítica a la conducción de Salvador Allende. En su edición del martes 11 de septiembre, editorializó con el siguiente título la situación del momento: "La única salida". Allí el periódico más antiguo y vigente de Concepción señalaba que la única salida a la crisis institucional por la cual atravesaba el país era la renuncia del presidente Allende; al respecto, "para salvar la democracia y para que una guerra fratricida no enlute los hogares y termine de destruir este país que tanto orgullo nos dio como chilenos, es la renuncia ahora mismo -sin una espera dilatoria que podría ser fatal- del Jefe del Estado y de los Parlamentarios". Allende debe dejar su cargo. "Su responsabilidad para con los hombres y mujeres de esta tierra debe llevarlo igualmente a aceptar la salida y evitar, como lo ha prometido, la guerra civil. El pueblo espera la respuesta" (Diario El Sur, 11-IX-1973: 3).

Consumado el golpe de Estado, en su edición del día 12, diario El Sur dio cuenta de la situación que se vivió en ese entonces, señalando que el momento que vive Chile viene a ser el duro precio de las circunstancias acumuladas durante tres años de gestión gubernativa (Diario El Sur, 12-IX-1973: 4). Las primeras expresiones del diario son bastante genéricas y hasta conciliadoras, realizando un llamado a la tranquilidad de la población, señalando que lo más importante es el país y su gente, quienes deben encontrar la paz social. Solamente en las primeras líneas de la editorial, se alude a la "responsabilidad" que tuvo la Unidad Popular en la crisis que experimentó el país. Este discurso cambió abruptamente con el transcurrir de los días y semanas. De la misma forma, el diario, en correspondencia con el discurso oficialista militar, desplegó toda una campaña mediática y discursiva tendiente a justificar el golpe de Estado y enaltecer el accionar de las Fuerzas Armadas. 
Ya el mismo día 12 de septiembre señalaba que en la tarde, tras la rendición de La Moneda, fueron izados los pabellones patrios en todas las casas de Concepción y en los edificios públicos. "Chile empezaba una nueva era en su historia libre y democrática" (Diario El Sur, 12 de septiembre de 1973, p. 2).

El editorial del 14 de septiembre resultó ser bastante ilustrativo, bajo el título "limpieza interna", el periódico aludió fundamentalmente a la crisis por la cual atravesaba el país, al papel restaurador que estaban cumpliendo las Fuerzas Armadas, la presencia de extranjeros (extremistas) en el país, quienes ocuparon cargos en la administración del Estado; incluso, con participación armada en distintos actos; por lo tanto, la tarea de asegurar una paz cívica duradera contiene el imperativo de ejercer el más estricto control sobre las actividades de los extremistas, como se ha estado haciendo hasta ahora. Es preciso continuar el procedimiento de poner en la frontera, de inmediato, a todos aquellos elementos que por un instante llegaron a pensar que lograrían sus objetivos desintegradores de la nacionalidad, al incitar a la violencia (Diario El Sur, 14-IX-1973: 3).

En concordancia con aquel discurso, y con motivo del aniversario patrio del 18 de septiembre, el editorial de aquel día daba cuenta del proceso de "limpieza interna" que se estaba desarrollando. Los allanamientos practicados en residencias oficiales, sedes partidarias y viviendas de militantes marxistas, no dejan lugar a ninguna duda de que se esperaba el momento propicio para dar el golpe de mano definitivo, a cualquier precio, que les permitiera a la izquierda hacerse del poder total. Ese golpe de mano, sería corroborado -según diario El Sur- con los miles de documentos encontrados en la Subsecretaría del Interior, los cuales daban cuenta del "Plan Z" a efectuarse el 17 de septiembre, el cual consistía -prosigue el medio- " ...en eliminar a toda la jerarquía de las Fuerzas Armadas y Carabineros y los dirigentes de los sectores democráticos, para quedar con el país a merced del totalitarismo definitivo". De ahí, entonces, la importancia de explicar al mundo los alcances de dicho plan, tal como lo están haciendo varios dirigentes gremiales, quienes ya recorren América Latina y Europa para exponer la verdadera situación nacional (Diario El Sur, 18-IX-1973: 3).

Mismas expresiones tuvo El Diario Color, al comentar el momento de trance que vive Chile y la responsabilidad patriótica que tienen las Fuerzas Armadas de sacar el país adelante. Por eso era importante tener presente que, producto de la gravedad de la situación en la cual se encuentra el país, la población debe estar consciente o tener presente que los males que aquejan al país no pueden solucionarse "por la sola presencia de los militares en el Gobierno"; dicha tarea necesita "un esfuerzo nacional, el trabajo tesonero de todos los chilenos entregados en alma y vida al proceso productor, pueden librar a la patria de sus profundos males económicos. Así lo ha comprendido la Junta Militar, que no ha vacilado, incluso, en ordenar la transformación 
momentánea, del día 19 de septiembre, destinado a festejar las glorias del Ejército, en un día normal de trabajo y esfuerzo" (El Diario Color, 20-IX1973: 3).

Incluso el 18 de septiembre constituyó una buena y oportuna fecha para "reflexionar" sobre las complejas horas que vivió el país. "No será este, como tradicionalmente se acostumbra, un Dieciocho caracterizado por las grandes fiestas. No se verán las típicas ramadas y los actos oficiales se reducirán al mínimo; casi exclusivamente al canto del Tedeum de Acción de Gracias, para pedir que la bendición del Todopoderoso ilumine el futuro de un pueblo que sale de la postración y la amargura y pugna por levantarse de la crisis que había sido arrastrado". De la misma forma, los habitantes de Concepción, debían aprovechar esta fecha para reflexionar en familia e intentar encontrar de nuevo el alma de Chile que permita construir un país independiente y soberano; aquello será posible, gracias a la tarea de las Fuerzas Armadas que hoy nuevamente permiten que la población pueda respirar un aire de libertad, evitando con su accionar que el país cayera en la dominación de un régimen marxista al más puro estilo totalitario y dictatorial (Diario El Sur, 18-IX-1973: 3).

Será la referencia a la figura de Diego Portales, la cual se "invocará" como ejemplo para superar la crisis que experimenta el país. Así lo dejó establecido el editorial de El Diario Color del 24 de septiembre: "El ejemplo de Portales". Para el editorialista, el Ministro constituye un "ejemplo de austeridad, orden, disciplina y progreso". Por lo tanto, con el cambio de nombre del edificio de la UNCTAD, ahora llamado Diego Portales, la Junta Militar notificó al país lo que será su política en el futuro: "Organización, disciplina, austeridad y esfuerzo nacional para sacar a la nación del caos económico en que se encuentra. Portales dictó normas rigurosas y prácticas que encaminaron al país por una senda de indiscutible progreso y bienestar. Desde entonces, Portales es sinónimo de organización y disciplina y las Fuerzas Armadas, que encarnan el ideal portaliano, aspiran, por ese camino, lograr poner en marcha a la nación, sacándola de su postración y pobreza, para lograr su definitiva emancipación" (El Diario Color, 24-IX-1973: 3).

En materia de ayuda y cooperación, la campaña de reconstrucción nacional fue una de las informaciones que recibió mayor cobertura entre septiembre y diciembre de 1973. En las páginas de El Sur y El Diario Color era posible apreciar los montos de las donaciones y quiénes eran las personas, instituciones o agrupaciones que concurrieron a realizar los aportes. Entre ellos se puede mencionar a familias, joyeros, ingenieros CAP, jubilados, centros de madres, casas comerciales, colectividades, etc.

Un mes después, se insistió en el importante papel que ha venido desarro\|lando "Concepción y el apoyo a la reconstrucción nacional". La rápida acción 
de las Fuerzas Armadas, ha permitido que Concepción "esté desenvolviendo sus actividades dentro de un marco que, podría decirse sin exagerar, está ya muy cercano a la normalidad total". Se pensó que por las actividades que se desarrollan en la zona, la Junta Militar encontraría mayores dificultades, sin embargo, "los representantes de la Junta de Gobierno en Concepción han desempeñado una labor y un papel que ha superado los cálculos más optimistas". ¿En qué se tradujo aquello?, en el funcionamiento de las actividades laborales, comercio y administración pública. "Un raudo paseo por las calles de Concepción, de Talcahuano o del resto de la zona, constituyen el mejor documento para reiterar la afirmación de que ésta será seguramente, una de las provincias que en el más breve plazo alcance su desarrollo integral" (El Diario Color, 8 y 24-X-1973: 5 y 3).

En el caso del diario Crónica, uno de sus primeros editoriales llevaba por título "Los grandes traidores". La columna, escrita en forma de carta, tenía un destinatario, los militantes de la Unidad Popular. En su primera parte señala "Señores militantes de la UP" y en ella el editorialista comentó con un dejo de ironía que durante el allanamiento realizado a una de las "tres residenciales palaciegas de quien fuera Presidente del "Gobierno Popular", se encontró una importante cantidad de dinero, ciento cuarenta mil dólares. Misma situación ocurrió en la casa del abogado que defiende a Carlos Altamirano, "autor confeso de la acción criminal que se planeaba contra la Armada, que incluía el asesinato masivo de oficiales", donde se encontraron maletas repletas de fajos de billetes de cinco mil escudos, aún no salidos a circulación. Estas acciones, no hacen otra cosa que demostrar en los hechos que, "en los momentos en que a ustedes los engañaban con la promesa del paraíso marxista, ellos se farreaban la revolución que les ofrecieron, en una orgía permanente de saqueo y despilfarro"; por lo tanto, los grandes traicionados son aquellos que confiaron en las promesas del marxismo. Entonces, si por cualquier circunstancia, estos mismos sujetos, estos traidores "aparecieran para empujarlos a un suicida e inútil baño de sangre, bien saben cuál debe ser vuestra respuesta. Porque para el traidor hay una sola respuesta" (Diario Crónica, 19-IX-1973: 17).

Por lo tanto, la reconstrucción del país no sólo debía darse en el campo económico o político, también en el ámbito de la moralidad, que es uno de los pilares básicos en que se sustenta el respeto de un pueblo hacia sus autoridades. Así lo han planteado los representantes de las Fuerzas Armadas y Carabineros y así lo pide el pueblo (Diario El Sur, 24-IX-1973: 3).

El apoyo a la Junta Militar también incluyó la defensa ante los ataques que se recibieron desde el extranjero, a través de campañas de desprestigio y desinformación. Una de ellas fue la intervención a comienzos de octubre del canciller Ismael Huerta en las Naciones Unidas. Discurso que no fue -en 
opinión del medio- el típico de "político profesional", sino el de un "oficial de las Fuerzas Armadas", caracterizado por su "sobria, detallada y concisa ponencia" y aclaratoria exposición que echó por tierra toda una campaña sostenida a nivel mundial por países que, lógicamente, no ven con buenos ojos que Chile haya desterrado el camino del marxismo para elegir, o, más bien, reencontrar su tradicional senda del desarrollo democrático, libertario y pluralista. En consecuencia, la presencia chilena en la ONU ha sido entonces fructífera y reconfortante. El mundo tendrá que valorar debidamente las palabras del canciller Huerta para así sacar conclusiones valederas, basadas en fundamentos verdaderos y no en la tergiversación de la realidad, como ha ocurrido en alguna medida y con algunos países (El Diario Color, 11-X-1973: 3).

El "ataque a la Embajada chilena en París", también significó un respaldo editorial. Este tipo de acciones se enmarca en una nueva fase de la escalada contra Chile, por parte del "comunismo internacional". Lo llamativo es que esta campaña cuenta con el apoyo de chilenos "que han descubierto una manera fácil de ganarse la vida, ya que son financiados internacionalmente para desprestigiar a su patria". Desde el extranjero difunden propaganda a través de panfletos e impresos en diversos idiomas, en los cuales hacen "una serie de afirmaciones absolutamente falsas y que son firmados por un supuesto Comité de Solidaridad". Si bien "todos" saben quiénes están detrás de esta campaña, la cual, además, está destinada al fracaso, se necesita enfrentarla y denunciarla públicamente por un principio de "objetividad y la más elemental noción de ética" (Diario El Sur, 10-XII-1973: 13).

Por estas actitudes "antichilenas", se aplaudió que el gobierno tomara la determinación de "cancelar la ciudadanía" a todas aquellas personas que se presten o participen de campañas de desprestigio contra Chile. Informaciones que sólo han causado un daño al país, al punto de señalar que en Chile se dio un "golpe militar", similar a otros países: "ha sido, justamente, esa falsa interpretación la que ha permitido dañar severamente la imagen de nuestro país". Estos "malos chilenos", no dimensionan el daño irreparable que le están causando a Chile, en su prestigio de nación respetuosa de los derechos humanos y con una larga y profunda trayectoria democrática.

En vista de estas gravísimas actitudes, especialmente de los ex militantes de la Unidad Popular o "jerarcas del régimen pasado" que se pasean por Europa, es que la pérdida de la nacionalidad "debe estimarse acorde con la magnitud del delito cometido" (El Diario Color, 12-XII-1973: 3).

Los noventa días de gobierno de las Fuerzas Armadas fue una buena fecha para expresar el beneplácito con las nuevas autoridades. Crónica señaló que una vez superada la etapa de orden y normalización (11 de septiembre y semanas posteriores), viene ahora el trabajo de la "reconstrucción nacional" (Diario Crónica, 12-XII-1973: 17). 
Haciendo un recorrido histórico, desde la independencia hasta el presente, El Diario Color realizó una breve síntesis de estos tres meses de administración, siendo las Fuerzas Armadas "la piedra angular de la nacionalidad" y de cada momento histórico del país. El 11 de septiembre de 1973 ha significado una fecha fundacional para el país, "una nueva era para la vida ciudadana, sin demagogia, sin atención de intereses electorales, sin aceptar que monopolios y grupos económicos poderosos pasen a ser los rectores de la actividad gubernativa que surgió en septiembre, como consecuencia del clamor de la inmensa mayoría ciudadana" (El Diario Color, 11-XII-1973: 3).

Dos fueron los temas que con fuerza se hicieron presentes hacia fines del año 1973 y durante todo el año 1974, el primero de ellos serán las denuncias contra la Junta Militar de Gobierno por las violaciones a los derechos humanos; el segundo, relacionado con el anterior, las críticas y cuestionamientos internacionales por las medidas represivas que estaba tomando el régimen. Ante ese escenario, ¿qué actitud tuvieron los periódicos locales, qué ideas y comentarios circularon por sus editoriales? Una de las primeras respuestas, se pudo leer en el editorial de El Diario Color de fines de marzo, donde criticaron "La campaña de rumores" que vienen del extranjero y también en Chile, concretamente al señalar que -supuestamente- en el país se han ejecutado más de diez mil ciudadanos, que existen verdaderos ríos de sangre en las calles capitalinas y que el Mapocho ha dejado de ser lo que es para recibir los centenares de cadáveres que a diario se acumulan en pleno centro capitalino, mientras que acá en Chile, se habla de ejecuciones sumarias en la vía pública y con montones de cadáveres que se encuentran en cada esquina. Todo esto no es más que el producto de una frondosa imaginación, digna de una novela de ciencia ficción (El Diario Color, 28-III-1974: 2).

Esta campaña internacional contra Chile, manejada y financiada desde Moscú, sostenía el medio, tiene sus propios agentes que no sólo operan abiertamente, sino que también de forma solapada, por eso el Gobierno y los medios de difusión deben estar alertas ante la calumnia que a nivel internacional está montada en contra de la Junta Militar y pueblo chileno, incluso apoyada por países con los cuales Chile ha tendido vínculos de profunda amistad, como el caso de México; sin embargo, ese país, hoy pretende cuestionar al gobierno de Chile, por el tema de los Derechos Humanos, dando paso con su actitud a la infamia y calumnia, la cual no puede ser aceptada por los miembros de las Fuerzas Armadas. No obstante toda esta campaña e infamia internacional, "la verdad saldrá a flote con el paso del tiempo" (El Diario Color, 20-V-1974: 8).

Pero no es solo Moscú o México, quienes forman parte de esta campaña de desprestigio contra Chile, también está Cuba, Italia y Francia. Esta forma de terrorismo internacional, "que es lo mismo que el marxismo internacional, 
ha proseguido con implacable constancia su campaña de ataque en contra de Chile y su Gobierno" (El Diario Color, 30-V-1974: 2).

A tal punto llegará la defensa de la Junta Militar sobre el tema de los derechos humanos, que con motivo de las sugerencias planteadas por la Comisión Interamericana de Derechos Humanos el año 1974, Diario El Sur señaló que compartía las declaraciones del canciller Patricio Carvajal, en el sentido que en el país se resguardan plenamente los derechos de las personas, al punto que los familiares de los detenidos están suficientemente informados y que se aceptan las visitas, que se ha permitido la salida del país y que se ha reconocido el derecho de asilo, que la legislación asegura la separación de los menores en los establecimientos de reclusión, que se observa el libre ejercicio profesional y que los abogados tienen toda clase de facilidades para intervenir y nadie queda en la indefensión al ser juzgado en los Consejos de Guerra. Por lo tanto, las sugerencias de la Comisión, así como las acusaciones que se realizan contra Chile en materia de respeto a los derechos humanos, no son otra cosa que una "campaña interesada y sostenida del marxismo internacional, que persiste en enlodar, mediante la mentira y la calumnia, la justicia de los procedimientos que se emplean en Chile y el esfuerzo mancomunado de su pueblo por sacar adelante al país, levantándolo de los postración a la que había sido arrastrado" (Diario El Sur, 12-VIII-1974: 5).

Según estos editorialistas, el recurso que más se está utilizando es denunciar que en Chile "se vulneran los Derechos Humanos, que aquí los ciudadanos son detenidos, torturados y encarcelados sin que puedan contar con asistencia jurídica", lo cual -según el editorial de El Diario Color del 13 de agosto de 1974- es totalmente falso; incluso, uno de los sistemas empleados por los marxistas, es el uso y abuso de los recursos de amparo que presentan ante los tribunales de Justicia, los cuales han sido rechazados por los respectivos tribunales, ya que estos recursos "corresponden a personas de nombres simulados, inexistentes"; sin embargo, los marxistas, aprovechan aquello para decir que "en nuestro país se oculta a los detenidos y que se hace tabla rasa de las atribuciones del Poder Judicial" (EI Diario Color, 13-VIII-1973: 2). Por el contrario, existe un poder Judicial que funciona normalmente y además de manera independiente, que no "ha sido perturbado en su organización, prerrogativas y atribuciones" (EI Diario Color, 7-IX-1974: 2).

También existieron otras formas de demostrar al mundo la adhesión que tenía el general Augusto Pinochet y las Fuerzas Armadas; un ejemplo de aquello es lo realizado por el alcalde de Concepción, Alfonso Urrejola, quien en mayo de 1974 designó hijo ilustre de la ciudad al general Pinochet. Este tipo de acciones, que pueden ser pequeños gestos, constituyen una de las mejores demostraciones del entusiasmo y agradecimiento que expresa la 
ciudadanía con la Junta Militar. "En todos los puntos del territorio nacional donde ha llegado el Presidente de la Junta de Gobierno se ha repetido la misma situación. Esto es, la adhesión a su persona, actitud que involucra un respaldo a la gestión de las Fuerzas Armadas en la conducción del país" (Diario El Sur, 7-V-1974: 5).

Una de las batallas post 11 de septiembre, se localizó en el campo educacional universitario. En este último caso, situamos a la Universidad de Concepción, que -de acuerdo a las autoridades militares-en los últimos años había estado "controlada y sojuzgada por un grupo de extremistas", que se habían "adueñado del mando y se daban maña para ejercerlo sin contrapeso", teniendo en su interior a seudodocentes y seudoalumnos "que con el cartabón de profesores o de alumnos cumplían exclusivamente funciones de activismo político a expensas del presupuesto universitario". Todo cambió, con la designación de los rectores delegados, las Universidades, poco a poco han ido volviendo al sitial que nunca debieron perder, y en aquella tarea el rector delegado Guillermo González Bastías ha cumplido un rol fundamental, recuperando a la Universidad, no sólo para los universitarios, sino para la ciudad. Hoy Concepción ha recuperado su Universidad y vuelve a sentirla como plena y entrañablemente suya. La Universidad de Concepción retornó a su verdadera esencia, a su espíritu, a su sentido prístino del que jamás debió apartarse (El Diario Color, 13-I-1974: 3).

La reorganización de las Universidades debe ir acompañada de la disciplina estudiantil y la tarea y responsabilidad de la juventud en esta nueva etapa que inicia Chile. "Justamente estuvo en las escuelas, liceos y universidades el peor foco del caos y la anarquía". Y eso ¿debido a qué? A una educación gratuita, que los estudiantes se farrearon y, por otro lado, a la influencia del marxismo en los jóvenes, perturbando sus valores y su formación.

A propósito de la inauguración del año escolar 1974, y en la nueva política en materia educativa, tendiente a la transformación material y espiritual, se buscó "imprimir un sello chileno y nacionalista, cristiano y humanista a la educación". Los alumnos debían responder con el estudio y dedicación a las tareas escolares. En cuanto a materias y contenidos, se dio especial atención y énfasis "a la historia de Chile y se inculcará el máximo de reflexión en cuanto al significado de los símbolos nacionales -Bandera y Escudo chileno-, todo esto con miras a la toma de conciencia del significado de nuestros valores fundamentales". La nueva política educativa, se sintetizó en la siguiente frase: "el profesor enseña y manda; el alumno estudia y obedece" (Diario El Sur, 11-III-1974: 9 y 13).

Por eso fue necesaria una intervención en esta área, que por muy rigurosa que sea, es ineludible, "como lo es la intervención quirúrgica, cuando el mal no admite ya otra alternativa para salvar al enfermo. En el caso del 
estudiantado chileno, el mal estaba ya demasiado avanzado" (Diario Crónica, 22-III-1974: 17).

Son estas las medidas del gobierno, su tarea conductora y el nuevo ritmo que ha imprimido a la administración del Estado, lo que ha generado "la adhesión de la ciudadanía". Esta solicitó al gobierno autorización para realizar una concentración con motivo de celebrar el primer aniversario del "pronunciamiento militar del 11 de septiembre de 1973". Manifestación que constituye la mejor prueba del compromiso que tiene el pueblo de Chile con sus Fuerzas Armadas y Carabineros.

La población, quiso expresarse públicamente y agradecer a la Junta Militar esta fecha histórica, que constituyó una "virtual segunda conquista de la independencia de la nación". La respuesta sólo la tiene la Junta Militar, la cual ha sido testigo de todas las muestras de adhesión que ha tenido durante este primer año de gobierno.

A pesar de las dificultades con las cuales han debido bregar las Fuerzas Armadas y Carabineros, la Junta puede mostrar al mundo un país recuperado en sus formas normales de actividad, dispuesto a remontar los índices de crisis y de ruina que heredó de la administración de la ex Unidad Popular. Esta es sin duda su mayor satisfacción y un motivo justo de orgullo para todos los chilenos (El Diario Color, 27-VIII-1974: 2).

Chile vivió la experiencia política más nefasta de su historia, que intentó imponer por la violencia un sistema absolutamente ajeno a la idiosincrasia nacional, pero fue gracias a la resistencia civil de las mujeres, los estudiantes, los gremios y profesionales, quienes hicieron frente a este proyecto totalitario. Ante la resistencia de la población y de las instituciones de la república, "el marxismo decidió jugar su última carta. Obtener con sangre lo que no pudo ganar por el convencimiento. Y preparó la guerra civil, armando al extremismo, importando mercenarios y dando forma al diabólico Plan Zeta" (Diario Crónica, 11-IX-1974: 21).

A contar del 11 de septiembre de 1973, el país comenzó progresivamente a retornar a la normalidad institucional. Al cumplirse el primer aniversario del "pronunciamiento militar", el "corazón de los chilenos viste de fiesta". Si bien algunos, aún están siendo juzgados por las leyes nacionales y otros tantos, "se fueron al extranjero, para seguir al servicio del marxismo internacional", el país hoy se encuentra en una situación absolutamente distinta a como estaba en septiembre de 1973. "Ha retornado el orden, el trabajo, la confianza y la tranquilidad", por lo tanto "hay razones suficientes para vestir de fiesta y engalanar nuestra ciudades, calles y hogares con legítima alegría" (Diario El Sur, 11-IX-1974: 67). 
En consecuencia, en estos doce meses de gestión, la tarea restauradora de la Junta Militar de Gobierno ha sido inmensa, ha traído tranquilidad, orden, progreso, limpieza moral de los actos públicos. Por lo tanto, "solo hay una palabra que lo resume todo, gracias" (Diario Crónica, 11-IX-1974: 21).

\section{Las voces públicas: columnas de opinión}

Hemos utilizado la denominación voces públicas para representar aquellas opiniones que circularon en los diarios locales a través de las columnas de opinión. En medio del control ejercido por los militares y la censura (y autocensura) establecida a la prensa, fueron "privilegiadas" (seleccionadas) las (pocas y reiteradas) voces que tuvieron espacio o tribuna pública en los medios periodísticos de la época.

Al respecto, es posible identificar a una veintena de columnistas que tuvieron tribuna y de manera constante escribieron en lo diarios en los inicios de la dictadura cívico-militar. Ellos fueron la expresión de aquellos sectores de la sociedad en Concepción que respaldaron el golpe de Estado y las acciones que impulsó la Junta Militar. Los nombres que con mayor fuerza se repiten en las páginas de los diarios son el escritor Ricardo Boizard, conocido como Picotón; Capitán de Navío (no nos fue posible identificar su nombre); Raúl Morales Álvarez, cronista y reportero; los periodistas Juan Mansoulet, Francisco Wilson, Hugo Pérez López y René Sepúlveda Valenzuela, este último presidente del Colegio de periodistas de la región. Asimismo, encontramos las opiniones de algunos abogados, específicamente Hugo Díaz Uribe y Sergio Carrasco Delgado.

¿Qué escribieron o reflexionaron estas "voces públicas"? Aquello dependerá del columnista; mientras los abogados, es el caso de Uribe y Carrasco, se abocaron a escribir sobre aspectos jurídicos, legales, institucionales o la figura de Diego Portales, el resto hará uso de su pluma para justificar el golpe de Estado, analizar las medidas que determinó la Junta de Gobierno, destacar y apoyar ciertos valores y actitudes que las Fuerzas Armadas estaban promoviendo entre la población y "acometer" contra los sectores de izquierda o los críticos del régimen. Estos últimos serán catalogados de antipatriotas, enemigos de Chile, extremistas o indeseables. Finalmente nos encontramos con aquellos columnistas que expresan una adhesión e incondicionalidad absoluta con el nuevo régimen. Transformando sus tribunas en una especie de "trincheras" de opinión, desde donde atacaron de una manera virulenta, con sarcasmo y hasta con desprecio a los opositores. Aquí situamos a Raúl Morales Álvarez, Ricardo Boizard y Capitán de Navío, este último, en menor medida.

El martes 11 de septiembre de 1973, Diario El Sur reprodujo una columna de opinión del padre Raúl Hasbún, uno de los principales críticos del gobier- 
no de Salvador Allende, partidario del golpe de Estado y de la dictadura de Augusto Pinochet. Allí, en una larga exposición, Hasbún aludió -entre otros aspectos- al caso de determinados políticos chilenos que debieron enfrentar situaciones difíciles y complejas, ya sea como presidentes o ministros de Estado. Uno de aquellos casos fue el del presidente José Manuel Balmaceda, quien -de acuerdo a Hasbún- se dejó llevar por la obcecación y confusión, provocando con ello una dolorosa situación para él y miles de chilenos.

El ejemplo de Balmaceda, sirvió a Habún, para indicar que "Hoy, Chile vive horas de profundo desconcierto y todo parece indicar que el 'dilema doloroso' debe hacerse presente para nuestro gobernante o piloto", "un pueblo entero -presente y futuro- no admite seguir siendo sacrificado a una sacrosanta ideología, impuesta como un dogma irrecusable; extraña y ajena al clima nacional". Por lo tanto, "Cuando el piloto equivoca el rumbo o pierde la orientación que surge de la propia comunidad a la cual se debe, quedan dos alternativas (en este caso para Salvador Allende). La una, perseverar en el error, la otra y nuestra historia política presenta los ejemplos superiores dichos, enmendar, substancialmente y ceder a lo justo, lo debido, lo patriótico de verdad. En suma, resolver el 'dilema doloroso' en beneficio de Chile" (Diario El Sur, 11-IX-1973: 3).

Dos días después de producido el golpe, apareció una columna firmada por V.H. la cual aludía al clima de tranquilidad y esperanza que comenzaba a experimentar el país, "Chile amaneció ayer con un nuevo rostro. Se advertía en las calles, en las impresiones de la gente, en los saludos efusivos entre amigos o conocidos, en la risa franca de los transeúntes y en los comentarios de toda voz favorable al brusco cambio producido pocas horas antes en la situación del país". Lo cual era complementado con la presencia de la bandera tricolor y su estrella que flameaba en los edificios y viviendas de la ciudad. Por otra parte, la presencia de carabineros y militares en las calles era vista por los transeúntes "con expresiones de franca acogida y sensación de dar seguridad". Aquel cuadro fue percibido por Diario El Sur como una manifestación del pueblo chileno que lo único que busca es "producir para forjar el futuro y el desarrollo del país, y de esta región pujante y rica en recursos de toda especie", así, "sin resquemores ni odiosidad, olvidando muchos momentos amargos y dejando de lado el divisionismo forzado entre hermanos a que los empujó la intromisión de ideas y de una doctrina ajenas al sentir del pueblo y de la idiosincrasia nacional. Surge, pues, el rostro de Chile; el rostro de alegría y optimismo con que los chilenos plasmaron su historia" (Diario El Sur, 13-IX-1973: 3).

Una columna del 14 de septiembre estaba firmada por "E" y se refería a las informaciones de la prensa internacional sobre lo ocurrido en Chile. Al respecto el columnista señaló: "La prensa europea y latinoamericana comenta 
con sorpresa el cambio de Gobierno ocurrido en Chile. Reconoce tácitamente las duras horas que vivía el país y cómo la situación se hacía insostenible. A la vez, deplora el quiebre del estilo tradicional de nuestras Fuerzas Armadas al salirse del marco de respeto a la legalidad, a la Constitución y al poder civil. Es fácil escribir, hablar y pensar así desde Europa, de cualquier capital latinoamericana o desde Estado Unidos. Es sencillo cuando no se han vivido tres años bajo el imperio del sectarismo, del abuso, de la procacidad y de una permanente ilegalidad. Cuando más importante que la calidad personal y profesional ha sido la posesión de un determinado carnet político. Cuando se ha engañado miserablemente a un pueblo que por años creyó en una doctrina que creía necesaria".

Para el columnista, la versión que circula en medios internacionales, no se condice con lo ocurrido en Chile, es más, si algún medio del extranjero quisiera conocer lo que está pasando realmente en el país, bastaría con visitarlo, recorrerlo y darse cuenta cómo las calles están embanderas anunciando un nuevo amanecer; "tendrían que mirar en los ojos de cada chileno bien nacido la luz de esperanza que la acción de las Fuerzas Armadas le permite abrigar" (Diario El Sur, 14-IX-1973: 3).

Resaltar el valor patriótico de las Fuerzas Armadas, fue uno de los conceptos que por aquellos días circularon profusamente en las columnas. Por ejemplo el periodista Juan Monsoulet y Clímaco Neira Sanhueza expresaban sus puntos de vista sobre el particular. Para el primero los antipatriotas "querían demoler y sumir a la nación en una catástrofe, para -sobre las ruinas- levantar la dictadura", son "chilenos que olvidaron su lealtad a la patria, querían a toda costa y costo, implantar el yugo de la servidumbre sobre sus habitantes", pero "iMenos mal! Gracias a nuestra buena estrella y a la sensatez y patriotismo de las Fuerzas Armadas, ha llegado, ha amanecido para Chile un nuevo despertar" (Diario El Sur, 14-IX-1973: 3).

Mientras que para Neira Sanhueza: "Mentalidades extraviadas habían arrastrado al país al descalabro sin precedentes; jamás registrado en los anales de la centenaria historia de nuestra República de tradiciones democráticas, libre y soberana. Pero, felizmente, los chilenos tenemos en nuestro seno el gran baluarte de nuestras gloriosas Fuerzas Armadas que, en un gesto patriótico que las enaltece, derribaron desde los cimientos el peso que nos agobiaba". Siguiendo el comentario de Neira, gracias a la intervención de las Fuerzas Armadas se logra palpar la alegría y emoción de los espíritus chilenos al ver cómo se enmienda el rumbo de la patria amenazada, lo cual nos hace gritar con voz potente y viril ¡Viva Chile libre!, "Gracias una vez más, a nuestras gloriosas Fuerzas Armadas y Carabineros, que han puesto a Chile en el más alto pedestal del civismo patriótico que honra a Chile y los Chilenos" (Diario El Sur, 15-IX-1973: 3). 
En una de las primeras columnas de Capitán de Navío, se refirió al fascismo rojo. Tomando una frase de Raúl Durán Dávila para calificar la dictadura de Fidel Castro, el columnista señaló que el fascismo no necesariamente tiene que ser negro o pardo, también es rojo, y su mejor expresión es la Unión Soviética. En el caso chileno, Allende originalmente se presentó con su vía chilena al socialismo, pero luego, "al darse cuenta de que el camino saldría imposible cayó en el increíble delirio de sus vicios y desvíos, protagonizando personalmente toda y cualquier aberración y permitiendo también protagonizarlas a los seguidores más preferidos de su corte extravagante", más aun, siguiendo las directrices de su "rector fascista del Caribe", Fidel Castro, planificó el asesinato de la jerarquía militar de Chile. Tal como lo han demostrado los documentos que se han encontrado, se pretendió llevar adelante un genocidio para el 18 o 19 de septiembre; sin embargo -agregó el columnista-, Allende quiso realizarlo en la misma mañana del 11 de septiembre, cuando se vio bombardeado en La Moneda. Fue por eso que pidió la presencia en el Palacio de los comandantes en jefes de la Fuerzas Armadas para ofrecerles su rendición. Pero su verdadero propósito era asesinar, apenas llegasen, al riesgo de morir él mismo en la furia de su hecho feroz. El Servicio de Inteligencia Militar ya lo había calculado. Una vez que lo comprendió, Allende decidió matarse, frustrado hasta en su último designio como alumno del fascismo rojo del Caribe (Diario El Sur, 15-IX-1973: 3).

Días más tarde, nuevamente publicó otra columna, esta vez bajo el título "después del drama". Ahora corresponde realizar el "necesario juzgamiento histórico de Salvador Allende", para eso se necesita hundir los dedos en la Unidad Popular, lo cual permitirá que aflore toda la maligna pus que la invadía y que se representaba en la vanidad, despilfarro, cinismo, sectarismo partidista, y sobre todo el odio, la violencia y el crimen. "Allende y sus seguidores marxistas de la Unidad Popular, fueron los principales artífices del terrorismo que estremecía a Chile", y como injurió a la Constitución y burló las leyes, las Fuerzas Armadas tuvieron que actuar para defender los destinos de país (Diario El Sur, 24-IX-1973: 3).

Por eso, después del 11 de septiembre "la Junta de Gobierno Militar está empeñada en despolitizar a Chile como una necesaria labor de urgente asepsia nacional". Con estas palabras, el Capitán de Navío comenzó su análisis sobre la tarea de despolitización que debió llevar adelante el nuevo gobierno. Esta tarea era necesaria y perentoria, ya que la Unidad Popular sumió al país en un caos que persiste en seguir flagelando a la sociedad, por eso es importante que el país entienda que "nunca más puede volver a producirse en Chile una experiencia tan funesta como la de Salvador Allende y la Unidad Popular. Esta exigencia de saneamiento nacional es la que obliga a despolitizar, aceptando y reclamando únicamente el interés de Chile por encima de toda y cualquiera otra bandería meramente partidista" y esa 
tarea solamente la pueden encabezar las Fuerzas Armadas y Carabineros de Chile, quienes sólo tiene como "partido" servir a la patria, que representa un sincronismo nacional de espíritus y corazones (El Diario Color, 9-IX-1973: 5).

Meses más tarde, y en su habitual espacio de comentarios "El revés de la trama", realizó un reconocimiento a un diferente primero de mayo. En esta ocasión, el día del trabajador no fue utilizado -según el columnista"como un barbecho de agitación política y social"; en esta oportunidad, la Junta Militar dispuso que el primero de mayo fuera celebrado como "una demostración en verdadero beneficio de los trabajadores, sin contaminarla con ninguna ambición meramente politicista" (Diario El Sur, 2-V-1974: 5).

Por eso mismo, los trabajadores, el pueblo, solidariza con las Fuerzas Armadas, porque ve en su accionar la grandeza de Chile y de su Patria. Especialmente en estos momentos, cuando desde el exterior se le ataca y critica. "Este cometido lleva al pueblo a la serena admisión de un verdadero estado de guerra con los enemigos de Chile, porfiados en injuriarlo y calumniarlo desde el extranjero"; sin embargo, el pueblo está dispuesto a luchar contra esta campaña y como en otras ocasiones y momentos de la historia nacional, va dispuesto a la lucha, hasta ganar la pelea (Diario El Sur, 3-VI-1974: 13).

Por aquellos mismos días, el presidente del Colegio de Periodistas de Concepción, René Sepúlveda Valenzuela, daba gracias -a través de las páginas de El Sur- a las Fuerzas Armadas por la oportuna intervención del día 11 de septiembre, ya que sin su efectivo actuar "mañana habría sido quizá demasiado tarde. A lo mejor no estaríamos pensando y escribiendo lo que ayer y hoy sentimos", ya que los seguidores de Marx y Lenin sólo causaron daño y destrucción al país. "Para eso las armas en abundancia; para eso los miles y miles de extranjeros indeseables; para eso la prédica enfermante de las consignas concientizadoras, que no trepidaban en pasar por encima de la dignidad de las personas, de sus derechos, con tal de conseguir fines sin importar los medios".

Gracias a las Fuerzas Armadas "guardadoras de los valores fundamentales", se logró truncar de raíz "el cáncer que ya amenazaba corroer la existencia y el futuro de los chilenos", por eso hoy, todos los chilenos sin distinción, se lo agradecen. En consecuencia, "Hoy damos gracias a Dios que estuvimos en la verdad y supimos expresarla con valentía teniendo presente a Chile, su historia, nuestro querido pueblo" (Diario El Sur, 16-IX-1973: 3).

Otra de las plumas que por aquellos días circuló copiosamente fue la de Francisco Wilson; sus opiniones se pueden leer tanto en diario Crónica como en El Sur. En una de sus columnas destacó el papel de la clase media, la cual luchó contra el marxismo, hasta vencerlo. ¿Dónde está esa clase media?, se pregunta Wilson; ésta se ve en los camioneros que lograron "doblarle 
la mano al amo marxista que no pedía ni daba rendición"; en las propias Fuerzas Armadas, "pura clase media, es decir, gente que cree en Dios, en la patria, en la dignificación del trabajo y en la disciplina entendida con la cual avanzan los pueblos que saben conquistar su destino". A lo anterior también se agregó a las mujeres y la juventud de los planteles secundarios, todos ellos forman esta clase media que hizo frente a los embates de tres años de marxismo (Diario El Sur, 18-IX-1973: 3).

El propio Wilson, dos días más tarde y con sus ojos humedecidos de emoción (así lo señala), escribió sobre el "peso de la noche". Al enterarse que el edificio de la UNCTAD pasó a denominarse Diego Portales. De esta forma, los militares, mientras se repara La Moneda, han reconocido la inmensa obra de un estadista que con "su Constitución del 33, nos enrielara por los caminos que harían decir a los países del mundo de esos años: Chile es el espejo y el guía de la democracia en los países de la América Latina". Así explicó su júbilo y alegría hasta las lágrimas: "El día 18, cuando supe la noticia, palabra que me dieron ganas de tomar una guitarra y cantar en cuello: ¡chitas que es linda mi tierra! La tierra por la cual Portales dio la vida, nuestra tierra libre soberana, chilenazo de ley, se le ha comenzado a hacer justicia. Qué orgulloso es sentirse chileno. Ahora más que nunca" (Diario El Sur, 20-IX-1973: 3).

Respecto a Diego Portales, resultó interesante leer cómo su figura, lo que fue su administración y los respectivos "valores y principios" que encarnó su persona cobraron vigencia en aquellos días. Este discurso encontró sustento y apoyo en personas vinculadas al ámbito del derecho, es el caso de los abogados Hugo Díaz Uribe y Sergio Carrasco Delgado.

Una de las columnas de este último se intituló "Sobre la tarea de gobernar. I. El pensamiento de Portales". En las primeras líneas, Carrasco Delgado señaló que en vista de las constantes alusiones que se han realizado en el último tiempo (post 11 de septiembre) sobre el pensamiento de Portales como "inspirador de la nueva forma de conducción política del país", se hace necesario esclarecer alguna concepciones políticas del Ministro estanquero. Para Carrasco Delgado, el ideario portaliano puede sintetizarse en los siguientes puntos: Sentido de renovación, Concepción de Gobierno Impersonal, Principio de autoridad, Probidad Administrativa, Criterio Nacionalista, y Realismo político y espíritu creador (Diario El Sur, 19-X-1973: 5).

El sentido renovador está dado porque con Portales se construyó un Estado moderno, dejando atrás los bandos, disputas políticas-ideológicas y la desaprensión por las materias económicas. El gobierno impersonal, envuelve "poner término al caudillismo y a la lucha estéril de las fracciones políticas", que los gobiernos son respetados en la medida en que la colectividad se sentía motivada por la gloria militar, el trasfondo ideológico o los devaneos intelectuales, "pero sin que la esencia del poder pudiera conservarse más 
allá de la persona que eventualmente ostentara el mando". Por eso buscó ejercer la función pública de un modo impersonal y como un deber cívico. Eso explica "que, aun desapareciendo su creador, la obra perdurara y se adentrara en el alma nacional". Junto con aquello, está el Principio de Autoridad, una obediencia absoluta a la ley, por medio de una autoridad rectora de la convivencia social, "pero para que esa autoridad fuese acatada debía obligar a todos por igual y no favorecerse al pariente, al amigo o al compadre", sólo, de esa forma el cuerpo social puede tener confianza en un nuevo régimen político, que fuera capaz de dar un adecuado gobierno a todos, resguardando el bien común (Diario El Sur, 19-X-1973: 5).

Días más tarde, el mismo Carrasco, en una nueva columna intitulada "Sobre la tarea de gobernar", analizó la "Nueva Institucionalidad", en el sentido que las autoridades han señalado que esta nueva institucionalidad se inspirará en el pensamiento y obra de Portales; "concordamos en que así debe hacerse", agregó el jurista; sin embargo, no se trata de trasladar lisa y llanamente una determinada realidad, como fue el Chile de la década portaliana, sino que la idea es que los grandes principios del ministro Portales "deben aplicarse a una realidad de hoy, que por cierto es substancialmente diferente a la de comienzos del siglo XIX". No obstante aquello, el gobierno en la construcción de una nueva institucionalidad, debe considerar algunos aspectos centrales, por ejemplo: Impersonalidad, autoridad y criterio nacionalista, nueva concepción de lo que significa la actuación pública y el papel de los gremios y de la base social, relevo generacional indispensable, predominio de lo técnico por sobre lo ideológico, construcción de una sociedad de participación creadora, vinculación estricta a la realidad chilena. En esta tarea es importante contar con la positiva influencia de los gremios y la base social. No para que éstos conquisten parcelas de poder o sean favorecidos, sino para recoger de ellos, el conocimiento que tienen de la realidad nacional, "pues de estas organizaciones -liberadas de las interferencias de la politización- tienen que salir voces limpias y no instrumentalizadas, al servicio de la conveniencia general y no de ideologías. El gremio es la célula de la nación, del funcionamiento armónico de estos organismos depende en gran medida el correcto desarrollo del órgano principal" (Diario El Sur, 23-X-1973: 5).

Un mes más tarde, la pluma de este abogado nuevamente se explayó in extenso, en esta ocasión sobre la figura de Jorge Prat Echaurren, un político nacionalista de gran actividad entre las décadas del cuarenta y sesenta del siglo $X X$. Recogiendo algunos pensamientos que expuso Prat en foros durante los años 1963-1964, Carrasco destacó los siguientes aspectos. Prat Echaurren fue un visionario que con anticipación advirtió lo que podía ocurrir en Chile. Por ejemplo, la politización del país que sólo trae como consecuencia divisiones, estancamiento y decadencia. Que en el país, existe los que se llama las "mayorías silenciosas", es decir, sectores que generalmente callan, a diferencia de 
unos pocos, que son los que habitualmente gritan y que se presentan como si fueran la mayoría. Lamentablemente los políticos no han prestado atención o escuchado a estas "mayorías silenciosas" y como consecuencia de aquello, el país vive un "proceso de liquidación nacional en que la legislación nacional, la administración y el Ejecutivo han sido víctimas permanentes de la debilidad y la flaqueza", lo cual se traduce en la decadencia que vive el país. Por eso Chile necesita ser reformado en sus aspectos políticos, sociales, educacionales y allí, en medio de aquella crisis institucional, se requiere dirigir un mensaje de esperanza a las mujeres y a los jóvenes; ellos serán los forjadores de una "patria reformada" (Diario El Sur, 9-XI-1973: 5).

¿Qué papel juegan las Fuerzas Armadas en todo esto?: "Las Fuerzas Armadas, incontaminadas por la política, servidas esencialmente por la vocación, en precarias condiciones económicas y en continuo hostigamiento político, son un verdadero baluarte para la chilenidad". Y en el caso-hipotético-que un gobierno decidiera entregar "lo que hoy día es nuestro", no quedaría otro camino a las Fuerzas Armadas, que salir de su vitrina. "Y en lo que se refiere a la defensa de nuestras instituciones y leyes, si ellas son atacadas, si ellas son puestas en peligro, tendrían también que salir de la vitrina", concluía el académico de la Universidad de Concepción (Diario El Sur, 10-XI-1973: 5).

En el caso de Hugo Díaz Uribe, tres son los aspectos sobre los cuales reflexionó, el primero de ellos es sobre la vigencia de los consejos de guerra. En una columna del mes de octubre de 1973, realizó todo un recorrido y análisis de lo que significaba la Justicia Militar y los respectivos consejos de guerra. De acuerdo a su interpretación, en el actual momento que vive el país (Estado de guerra interna) "Los delitos de jurisdicción militar, el procedimiento señalado y las autoridades judiciales mencionadas, a virtud del decreto de estado de sitio, tiene plena vigencia en estos días en el país" (Diario El Sur, 6-XII-1973: 5).

Una segunda opinión de Díaz Uribe se relacionó con los conceptos de libertad y legalidad. Planteando una crítica al gobierno de la Unidad Popular, señaló que durante aquella administración "para destruir la institucionalidad, desprestigió la legalidad y sus poderes generadores. Se habló así de "la justicia burguesa", de las "leyes burguesas", sobre las cuales y en posición de desacato se pusieron ellos". En el fondo se buscó establecer nuevas estructuras de poder por medio de valores distintos, lo cual pasaba por la destrucción del poder legal imperante. En la práctica significó avanzar por el terreno del libertinaje y la anarquía. "Esto que era una deformación de la democracia, se quiso hacer entender como la real libertad. Las consecuencias las tuvimos todos a la vista, en donde cualquiera quiso imponer su voluntad contra el deseo de los demás o contra el querer de las mayorías nacionales".

Esta forma de entender y practicar la libertad es lo contrario a la que emana del orden legal y que se conoce como "libertad jurídica". "Constituye 
un bien de la sociedad, de los ciudadanos y debe ser por tanto, objeto de protección, contra los que aspiran a la libertad anárquica". En vista de lo anterior, "sin acatamiento de la ley, no hay posibilidad certera de libertad". Este es uno de los puntos centrales que hoy nos debe hacer reflexionar, en torno a la crisis del Estado de derecho que culminó con la acción del 11 de septiembre de 1973 y al que el nuevo gobierno, la Junta Militar, busca restablecer por medio de los cauces institucionales (Diario El Sur, 16-XI-1973: 5).

Estas opiniones, lo llevaron a saludar con beneplácito las "bases de la Nueva Constitución" que la Junta de Gobierno estaba preparando a través de un grupo de juristas. Para Díaz Uribe, el país vivió en los últimos (tres) años un colonialismo intelectual y moral, que alienó la idiosincrasia misma del país. Era el alma nacional la que se entregaba a consignas, dictados y normas extrañas. "Se quiso imponer aquí valores reñidos con la personalidad del país". Por eso es tan importante y positiva la idea de crear una nueva Constitución Política, especialmente por los principios que ésta representa. Así se pueden destacar los "valores esenciales de la chilenidad" y la preservación de la "identidad histórica cultural de la patria", a lo cual se agregan una concepción humanista cristiana del hombre y de la sociedad. Estas concepciones, constituyen lo esencial de los "sentimientos morales del pueblo chileno", incluso los juristas que están encargados de una nueva Constitución "hacen al fin, un acto de reconocimiento, cuando elevan a la real categoría de valor de la nacionalidad chilena su raíz hispánica. No existe un mundo más propio para Chile que el hispánico".

Para estos columnistas, una nueva institucionalidad debe estar inspirada o por lo menos recoger aquellos elementos fundamentales del pensamiento portaliano y qué mejor que una nueva Constitución política, la cual-como señala Díaz Uribe- emanará "de valores permanentes del alma nacional" (Diario El Sur, 14-XII-1973: 5).

Dejando atrás las opiniones de estas dos "voces públicas" del ámbito del derecho, encontramos también algunas críticas a determinadas expresiones artísticas, culturales y representativas de la ciudad, fue el caso del cierre del Teatro de la Universidad de Concepción (TUC) y el despido de sus integrantes. A juicio de Gerardo Sepúlveda Coddou, el Teatro de la Universidad se prestó para que sus integrantes lo utilizaran "para sus mezquinas pasiones políticas", donde lo que menos se vio fue teatro. Aquel espacio se dedicó en el último tiempo a "realizar reuniones o asambleas, y con frecuentes participaciones en las concentraciones de la CUT, en las asambleas de la FEC y en las exposiciones sobre Cuba". Por eso -en opinión del columnista- el cierre del Teatro no debe constituir una pérdida o un hecho que lamentar, ya que no se podía esperar mucho o mejor dicho nada "de un organismo tan politizado, tan obsoleto en su concepción de lo dramático y tan mediocre en su calidad y capacidad 
artística". Por lo tanto, ante el cierre del Teatro y el cese de sus funciones de los actores, no queda otra que "aplaudir la determinación de las autoridades universitarias, porque teatro en Concepción no existía hace tiempo. No se justifican entonces, los salarios" (Diario Crónica, 17-X-1973: 17).

A propósito de la Universidad de Concepción, el jefe de informaciones de diario Crónica, el periodista Hugo Pérez López, comentó el discurso del Rector-Delegado, capitán de navío (r) Guillermo González Bastías y la "nueva Universidad de Concepción", que dejaba atrás aquella Universidad militante y comprometida con el proceso de revolución violenta. Citando pasajes del discurso de González Bastías, indicó que una de las tareas era la despolitización de la Universidad; "la política debe entrar en sueño y por largo tiempo". No se admitirá que ninguna de las ideas políticas logre enseñorearse de las aulas, cátedras o espacios universitarios, para así generar proselitismo y sectarismo, como ocurrió en el pasado.

Las palabras del Rector-Delegado -continuó el periodista- constituyeron un punto final, el término y lápida para todas aquellas prácticas desquiciadas que proliferaron en la Universidad, "para la politización en sus estamentos, para el desarrollo del odio, de las asambleas violentas, para el sueño de conquistar la ciudad con columnas de adolescentes despistados, enceguecidos sabiamente por quienes nunca dieron la cara y que hoy están escondidos bajo algún catre, en una clara demostración de lo que siempre fue su valentía revolucionaria" (Diario Crónica, 19-XI-1973: 17).

El mismo periodista, un mes más tarde, las emprendió esta vez contra Hortensia Bussi de Allende al señalar que la viuda del ex presidente ha inventado una nueva forma de hacer el ridículo, con características internacionales. Para Pérez López, Hortensia Bussi se pasea por el mundo contando una historia "y leyendo un libreto de mentiras que han puesto a su disposición quienes la pasean por el mundo como un trofeo", pero aun, hace el ridículo internacionalmente, como viuda del ex presidente Allende, cuando es sabido "que la tal viuda era tan sólo una pantalla para la vida pública y una figura sin pena ni gloria en la vida privada". Por eso llama la atención -señala el periodista- que hoy se convierta en oradora internacional, mientras que en Chile "no hablaba ni en las reuniones de los centros de madre" (Diario Crónica, 18-XII-1973: 17).

En el mismo tema, más directo fue Ricardo Boizard (Picotón) al comentar "Doña Tencha la pilló", en el sentido de que ella "ahora desempeña un papel estridente y preponderante en calidad de viuda", siendo que en Chile tuvo muy poco que ver con su marido; sin embargo, ahora se pasea por el mundo, alojando en los mejores hoteles y financia concentraciones en las cuales se ataca a Chile. ¿Cómo lo hace?, con apoyo y financiamiento del comunismo internacional, que le sirve para "explotar al máximo su calidad de viuda, ya 
que la calidad de Primera Dama en Chile, no fue ella quien la explotó sino la Payita" (Diario El Sur, 10-XII-1973: 13).

Sin duda, la "Columna de Picotón" destacará, no por su nivel de análisis o reflexión, sino por la mordacidad que destila de su pluma. En una de sus habituales columnas comentó: "Aquí no se ha asesinado a nadie como en tiempos de Stalin, aquí no existen campos de concentración como en lo extenso de Siberia y Rusia. Si ha habido algunos pocos muertos, es porque pretendieron atacar a las Fuerzas Armadas y, naturalmente, las Fuerzas Armadas procedieron en defensa propia. Si existen algunos personeros de la Unidad Popular sometidos a proceso, todo se realiza de acuerdo a las disposiciones legales y dentro de la más absoluta libertad que tienen los procesados para defenderse" (Diario El Sur, 15-IV-1974: 13). Incluso, agregaría en una nueva columna, en materia de asilo se respeta dentro de los actuales cauces legales. Incluso, aquel que no está de acuerdo con el actual régimen tiene derecho a Asilo, pero otra cosa es querer confundir esto último con la impunidad, especialmente para los "delincuentes que buscaron en las Embajadas una manera de burlar a la justicia", o de aquellos marxistas que quisieron socavar la disciplina militar, de "los que robaron a manos llenas en las empresas nacionalizadas que dejaron gigantescas pérdidas" (Diario El Sur, 6-VI-1974: 5). Estos son políticos o delincuentes, se pregunta Picotón. Indudablemente, hay delincuentes que, afortunadamente -en palabras de Boizard- se están marchando del país, claro que seguramente contarán las peores cosas de Chile. "Lo único terrible que no van a contar es que, habiendo sido delincuentes en el Gobierno, se les ha dejado salir sin ninguna dificultad y también sin ningún deseo de que vuelvan" (Diario El Sur, 26-VI-1974: 11).

Septiembre de 1974 tuvo connotaciones especiales, se cumplió un año del "pronunciamiento militar" y los columnistas pusieron lo mejor de su pluma al servicio de la causa que han venido defendiendo desde el mismo 11 de septiembre de 1973.

René Sepúlveda no escatimó elogios al señalar: "El día 11, fecha memorable para la Patria que comienza como a renacer de las cenizas y del fuego odioso que encendieron otros chilenos que, con la cabeza caliente y el corazón envenenado querían hacer una gran hoguera para quemar lo que ellos mismos un día habían adorado... Ese día tiene para los conciudadanos la validez que corresponde y que la historia se encargará mañana de grabarla a fuego".

Por eso es tan importante el mes de la patria, en primer lugar porque el día 11, "volveremos a encontrarnos las mismas caras que hace un año nos miramos, reímos, algunos lloramos pero todos abrazados respiramos profundo y dijimos a todo pulmón: ¡Viva Chile!"; y en segundo lugar, por el día 18 que se convierte en un complemento del 11 de septiembre, en el cual se concatenan el sentido de unidad nacional, de dignidad y de amor, "sin estos tres 
atributos cualquier mes nos da igual; pero septiembre, por estos dos hechos históricos -el día 11 y el 18- merece ser celebrado con mucha más alegría, y aunque tengamos que apretarnos el cinturón, por lo menos afinemos nuestras gargantas para gritar: ¡Viva Chile!" (Diario Crónica, 7-IX-1974: 13). Un "¡Viva Chile!" que sintetiza todo un año de esfuerzo y sacrificio en materia de reconstrucción nacional y para mantenernos unidos, especialmente ante la amenaza que aún persiste por parte de algunos "cabezas calientes" que quieren darnos el golpe por la espalda y retrotraernos al Chile del odio, del enemigo, de las piedras, las cadenas, balazos o "condenarnos a muerte en planes zeta". Por eso, este 11 de septiembre, primer aniversario del pronunciamiento militar, corresponde que nos unamos y brindemos desde Arica a la Antártida a través de un grito de esperanza y amor: "¡Viva Chile!" (Diario Crónica, 11-IX-1974: 21).

Raúl Morales Álvarez fue otra de las personas que durante el año 1974 comenzó a escribir columnas. A través de las páginas de El Diario Color, lanzó sus diatribas contra los opositores a la Junta Militar y, además, defendió la obra del régimen.

Aprovechando el jolgorio y algarabía oficialista por las celebraciones del primer aniversario, Morales Álvarez planteó que Chile rompió con la historia, que nuestro país hizo lo que nadie había logrado, "Su primer retroceso en 57 años de constante ascenso ha sido, pues, el que le ha causado la voluntad democrática de Chile, bajo la rectoría ejecutiva de las Fuerzas Armadas". Este es el mejor ejemplo que Chile puede mostrar al mundo, liberarse por su propio esfuerzo y sacrificio "de la caldera del diablo, aun viéndose al medio de su perverso infierno".

Fue la hazaña de las Fuerzas Armadas, al servicio del país, las cuales debieron levantarse contra el gobierno de Salvador Allende que estaba "cogoteando la dignidad de Chile". Su liberación debe ir acompañada de una conducción, la que sólo puede ser ejecutada por los uniformados, su pasión nacionalista, promoción técnica y don de mando.

En esta hora no se requiere, no se necesita de la politiquería o la ambición política, que lo único que hace es generar odio y divisiones. Son las Fuerzas Armadas las únicas que pueden conducir este proceso, "nuestra segunda independencia", en el que nos liberamos del marxismo-leninismo y al mismo tiempo "estamos rompiendo la historia para darle al mundo otra menos odiosa y más feliz canonizando la dicha democrática de la familia humana" (El Diario Color, 18-IX-1974: 3). 


\section{Algunas conclusiones}

De manera conclusiva y respondiendo a cómo la prensa escrita de Concepción a través de sus editoriales y columnistas reflejó el golpe de Estado de 1973, es posible señalar que el actuar de dichos medios en aquella coyuntura no es muy diferente de la postura de otros periódicos del país, los cuales durante el gobierno de la Unidad Popular desempeñaron una posición crítica y opositora a la gestión de Salvador Allende. La acción del 11 de septiembre de 1973 constituyó un hecho predecible y en algunos casos hasta anhelado, por ejemplo, para los diarios El Sur y Crónica; distinto es el caso de El Diario Color, el cual hacia el 11 de septiembre de 1973 tenía una clara identificación con la Unidad Popular; eso significó que a contar del golpe de Estado, este medio fuera intervenido por las nuevas autoridades y con ello pasara a cumplir un papel fundamental en el apoyo y defensa del régimen.

Por lo tanto, el golpe de Estado de 1973, o en palabras de la época, el "pronunciamiento militar" de las Fuerzas Armadas, constituyó la reacción ante el llamado mayoritario de la población, que por aquellos días hacia presente su rechazo a un gobierno de inspiración marxista y totalitario, el cual estaba ad portas de la guerra civil, el asesinato masivo de los opositores, en último término, había trasgredido un orden establecido y defendido por los sectores más conservadores de la sociedad penquista.

La intervención de las Fuerzas Armadas, no fue otra cosa que la respuesta patriótica al llamado de una ciudadanía -siguiendo el análisis realizado por dicha prensa- que exigía poner fin a los mil días de la Unidad Popular; de ahí, entonces, por ejemplo, los rostros de alegría y el embanderamiento de la ciudad de Concepción ante la presencia uniformada en sus calles y la etapa de normalidad en la cual se encuentra el país, al conmemorarse el primer año de gobierno.

Las informaciones que por aquellos días circularon en las páginas de $E I$ Sur, Crónica y El Diario Color, específicamente a nivel de editoriales y columnas de opinión, fueron claramente de una afinidad con el nuevo escenario nacional, constituían la manifestación más evidente de la postura oficial de estos medios, aquella de informar, dar cuenta de lo que estaba pasando, pero sobre todo legitimar la acción militar del martes 11 y meses posteriores.

De la lectura de sus editoriales y columnas, se desprende que la crisis de 1973, fue el resultado de la accionar deliberado del gobierno marxista de la Unidad Popular y los sectores que los respaldaban, a lo cual se sumó el apoyo del comunismo internacional y sus agentes internos que buscaron colonizar no sólo materialmente el país, sino también moral y culturalmente. 
Bajo ese contexto y en vista de los comentarios y opiniones que circularon profusamente a favor de la intervención militar y las medidas disciplinarias y punitivas que se estaban llevando adelante, cabe plantearse sobre el accionar y responsabilidad política de dichos periódicos, como medios de información masiva y de gran recepción entre la población de Concepción. La opinión e información que entregaba El Sur, Crónica y El Diario Color contaba con un nivel importante de credibilidad a nivel local y nacional, tanto por su historia como por el papel desempeñado previo al golpe de Estado de 1973, particularmente los dos primeros.

No cabe dudas -a la luz de los registros- que todos de una u otra manera vieron con beneplácito el accionar militar del martes 11 de septiembre, que endosó la responsabilidad de la crisis institucional al gobierno de Salvador Allende y que posteriormente difundió a través de sus páginas información coincidente con la postura oficialista de la Junta Militar de Gobierno y sus representantes locales; es decir, aquella que importaba a los militares y civiles que los respaldaban.

En ese sentido, puede que el actuar de estos diarios, fuera motivado por un miedo o temor a represalias por parte de las nuevas autoridades; sin embargo, a pesar de posibles represalias, que podían ir desde despidos o un recambio completo del personal, hasta el cierre definitivo de la empresa, las informaciones contendidas en sus páginas, en este caso en sus editoriales y columnas de opinión, fueron parte constituyente de un dispositivo mayor que buscaba que la población asumiera, y esto en términos de manipulación y del poder de la información, sin mayores cuestionamientos lo que estaba ocurriendo en el país.

Más allá de la descripción o presentación de los editoriales y columnas de opinión, cabe preguntarnos ¿qué hay detrás de los conceptos, por momentos despectivos, sarcásticos y hasta virulentos emitidos por los columnistas citados en el presente artículo?; ¿son simplemente el reflejo de un revanchismo político e ideológico?; ¿una vuelta de mano por los complejos momentos que vivenciaron durante el gobierno de la Unidad Popular?; ¿la simple genuflexión ante el poder militar disciplinario? o ¿sus opiniones están reflejando y representando una concepción de sociedad que en los últimos tres años, fue cuestionada y amenazada?, es decir, ¿una crisis hegemónica que tenía como pilares fundamentales los conceptos de orden, disciplina, jerarquía y progreso?

Dejando de lado aquellos aspectos o conceptos más virulentos y despectivos que se pueden leer en los editoriales y columnas de opinión, podemos señalar que las opiniones difundidas en estos espacios, constituyen por una parte la expresión de vastos sectores de la población que vieron en la llegada de los militares una especie de salvación o resguardo ante el peligro 
que significaba el avance de la izquierda y su proyecto transformador y por momentos transgresor de lo establecido. Protección en términos materiales, por ejemplo, la propiedad privada, pero también, en los aspectos culturales y valóricos, léase la pérdida de la idiosincrasia, las tradiciones nacionales, el respeto por la Patria. De ahí, el uso de un determinado lenguaje y aparato conceptual a la hora de significar la realidad del momento, concretamente los días y meses posteriores al golpe de Estado.

El lenguaje y conceptos utilizados, jugaron un papel primordial en la construcción social de la realidad. Los sujetos ordenan, aprenden y significan su propia realidad a través de los conceptos. La lucha por significar la realidad, constituye una lucha por redefinir los espacios y construir las conductas más apropiadas para la acción. Así por ejemplo, los conceptos de orden, disciplina, jerarquía, respeto, trabajo y progreso, entre otros, circularon profusamente en los espacios de opinión.

Estos conceptos no son neutrales o al azar, detrás de ellos se esconde toda una representación de la realidad, una forma de concebir y proyectar el mundo, por lo tanto, van estructurando la experiencia social. Inspiran determinadas pautas de acción de los individuos y grupos. En consecuencia, el lenguaje político utilizado por los editorialistas y columnistas de la prensa escrita de Concepción, especialmente en la coyuntura de 1973, es un lenguaje que además de representar un escenario, ideas, creencias y valores, incita a la acción de quienes reciben o leen aquel mensaje. De ahí entonces el papel desempeñado por estos medios escritos, los cuales no sólo se remitieron a retransmitir las informaciones emanadas desde el poder militar disciplinario, sino también asistir directamente en la persuasión de la población para que ésta aceptara sin mayor crítica el discurso oficial castrense y de aquellos civiles que colaboraron en aquella tarea.

\section{Referencias bibliográficas}

\section{Fuentes primarias}

Diario El Sur, Concepción.

El Diario Color, Concepción.

Crónica, Concepción.

\section{Fuentes Secundarias}

CABALLERO, C. (1997). "El Diario Color 1971-1977". Informe de Seminario para optar a título de periodista, Universidad de Concepción, Facultad de Ciencias Sociales, Departamento de Comunicación Social. 
CASANUEVA, F. (2002). Prensa y periodismo en Concepción 1833-2000, Concepción: Escuela de Periodismo Universidad Católica de la Santísima Concepción. Informe Comisión Nacional Sobre Prisión Política y Tortura (2004). Santiago: Ministerio del Interior.

LAGOS, C. (2009). El diario de Agustín: Cinco estudios de casos sobre El Mercurio y los derechos humanos (1973-1990). Santiago: LOM Ediciones.

LECHNER, N. (2006). Obras escogidas, Santiago: Lom Ediciones.

MONCKEBERG, M. (2009). Los Magnates de la prensa. Concentración de los medios de comunicación en Chile. Santiago: Random House Mondadori.

SOTO, A (2003). "Caricatura y agitación política en Chile durante la Unidad Popular, 1970-1973", en Bicentenario, Revista de Chile y América, volumen 2, número 2. 